\title{
Estimating impacts of bushfire and climate variability on streamflow in Victoria, Australia
}

\author{
YUHAN GUO ${ }^{1}$, Lu Zhang ${ }^{2}$, Yongqiang Zhang ${ }^{3}$, Zhonggen Wang ${ }^{4}$, and Hongxing Zheng ${ }^{5}$ \\ ${ }^{1}$ Institute of Geographic Sciences and Natural Resources Research CAS \\ ${ }^{2} \mathrm{CSIRO}$ Land and Water \\ ${ }^{3}$ Key Laboratory of Water Cycle \& Related Land Surface Processes, Institute of \\ Geographic Sciences and Natural Resources Research, Chinese Academy of Sciences, \\ Beijing 100101, China; \\ ${ }^{4}$ Chinese Academy of Science \\ ${ }^{5} \mathrm{CSIRO}$
}

June 23, 2020

\begin{abstract}
Bushfires are common in Australia and can cause vegetation loss and affect hydrological processes such as interception, evapotranspiration, soil water storage and streamflow. This study investigates bushfire impacts on catchment mean annual streamflow for 14 Australian catchments that have been severely impacted by the 2009 Victoria bushfire, the second worst bushfire disaster in Australia. A statistical approach based on sensitivity coefficients was used for quantifying the climate variability impacts on streamflow and the time-trend analysis method was used to estimate the annual streamflow changes due to bushfire respectively. Our results show that bushfire has caused a noticeable increase in mean annual streamflow in majority of burnt catchments for an immediate post bushfire period (2009-2015), when the bushfire impact on streamflow is evidently larger than the climate change impact. Furthermore, the bushfire impact on mean annual streamflow linearly increases with the burnt percentage area. These results provide strong evidence for evaluating large-scale bushfire impact on streamflow at small to medium sized catchments, and guidance for process-based hydrological models for simulating bushfire impacts on hydrological processes for the immediate period after bushfire.
\end{abstract}

\section{Introduction}

Hydrologic systems are dynamically influenced by both anthropogenic activities and natural variability (Pathiraja et al., 2016). Among them, bushfire is an important cause of hydrological change in fire-prone landscapes (Shakesby \& Doerr, 2006). Bushfire can result in vegetation loss and post-fire microenvironment temperature rise, which can change hydrological processes such as interception, evapotranspiration and soil water storage. Effects of bushfire on streamflow can be estimated using the paired catchments method (Liu et al., 2004). Many studies have been conducted to understand the hydrological change due to vegetation cover changes using the paired catchment method (Brown et al., 2005; Loon et al., 2019; Zégre et al., 2010). However, the paired catchment analysis has drawbacks since it only involves small catchments and is expensive to conduct (Zhang et al., 2011). An alternative method is to use the time-trend analysis which does not require control catchments and can be applied to small to large catchments.

Apart from anthropogenic activities, climate variability can significantly affect streamflow and should be considered when evaluating the streamflow response to vegetation change due to bushfire (Lane et al., 2005; 
Zhang et al., 2011). Several methods have been developed and applied to separate the effects of vegetation change and climate variablity (Tuteja et al., 2007; Zhang et al., 2008; Zhao et al., 2012). These methods firstly identify key factors affecting streamflow and estimate the total streamflow changes using observed data. The second step is to determine the changes in streamflow due to the key factors such as vegetation change caused by bushfire and then to attribute the remaining changes to other factors such as climate variability. These methods can provide consistent estimates of vegetation change and climate variability impacts on streamflow in the catchments being considered (Zhao et al. (2010)).

Many attempts have been made to quantify the impacts of bushfire on hydrology in the past five decades (Anderson et al., 1976; Brown, 1972; Daniell \& Kulik, 1987; Neary et al., 1999; Robichaud et al., 2000; Tiedemann et al., 1979). Some recent studies mainly focused on hydrological modeling in bushfire impacted catchments, aiming to better estimate the streamflow variation under bushfire impacts (Folton et al., 2015; Heath et al., 2014; Mannik et al., 2013; Papathanasiou et al., 2015; Seibert et al., 2010; Zhou et al., 2015). To date, most of these studies mainly investigated or evaluated the bushfire impacts on streamflow but few of them quantified the impact of climate variability.

This study aims to quantify the climate variability and bushfire impacts on streamflow for 14 catchments located in Victoria, Australia that have been severely burnt by the 2009 Victoria bushfire, the second severest national bushfire disaster. The specific objectives are: i) investigating annual streamflow trends from the 14 catchments; and ii) separately estimating the vegetation change caused by bushfire and climate variability impacts on streamflow using time-trend analysis and statistic sensitivity-based model

\section{Catchment Descriptions and Data}

\subsection{Catchment Description}

On Saturday 7 February 2009, the state of Victoria Australia experienced the highest temperature on record with $46.4^{\circ} \mathrm{C}$ followed by severe bushfires that burnt an area of over 350,000 hectares and caused 173 deaths, which was the second severest among Australia's worst natural disasters (Biondi \& De Luca, 2015; Foster et al., 2011). According to Cai et al. (2009), the 2009 bushfire event was preceded by a positive Indian Ocean Dipole (pIOD) event more so than El Niño events. More specifically, the lower rainfall and higher temperatures produced by pIOD aggravated the dry conditions that finally caused the wide range of bushfire in Victoria. As a result, around $363 \mathrm{~km}^{2}$ of forests in the Melbourne water supply catchments (Feikema et al., 2013) and approximately 24 gauged catchments in Victoria were affected by this severe bushfire event.

$<$ Figure 1 Here Please $>$

This study selected 14 unregulated catchments that without major water storages or extraction for human use burnt during the 2009 Victorian bushfire. These catchments are located within the southern part of Victoria, Australia (Figure 1). They are small to medium in size, ranging from $84.76 \mathrm{~km}^{2}$ to $629.16 \mathrm{~km}^{2}$. Their mean slope ranges from $14.2 \%$ to $32 \%$ and their mean elevations range from $273.1 \mathrm{~m}-968 \mathrm{~m}$. Soils in these catchments are characterized by deep gradational friable earths or loams as well as some shallow stony earths (Feikema et al., 2013), and they are generally deep with high hydraulic conductivities (Campbell, 1999). The vegetation types in this area are mainly wet sclerophyll Eucalyptus forests known as ash-type eucalypt forest dominated by E. regnans F. Muell. and E. delegatensis R.T (Feikema et al., 2013). More detailed catchment information is summarized in Table 1.

$<$ Table 1 Here Please $>$

Apart from the preliminary summary of selected burnt catchment attributes, detailed various fire severity proportions of total burnt percentage for burnt catchments were also collected (see Figure 2). Burnt area in majority of catchments are classified as high fire severity such as Crown Burn and Crown Scorch, except some lightly burnt catchments (e.g. Frenchman Ck Jun and Jamieson). Some catchments with relatively 
low burnt percentage have more severe burns. For example, the Murrindindi above Colwells only has $58.9 \%$ burnt percentage, but it is mainly composed of crown burn and crown scorch.

$<$ Figure 2 Here Please $>$

\subsection{Streamflow and meteorological data}

The daily streamflow data used in this study were obtained from the Australian Bureau of Meteorology (http://www.bom.gov.au/water/). The climate data including daily precipitation (P), daily incoming solar radiation, daily vapour pressure, daily minimum air temperature, and daily maximum air temperature came from the SILO Data Drill produced by the Queensland Department of Environment and Resource Management (https://legacy.longpaddock.qld.gov.au/silo/). The SILO data has reasonably good quality since its mean absolute error between gridded and gauged data at gauged locations is $1.0^{\circ} \mathrm{C}, 1.4^{\circ} \mathrm{C}, 0.15 \mathrm{kPa}$ and 0.40 $\mathrm{mm}$ /day for maximum daily air temperature, minimum daily air temperature, vapour pressure, and precipitation, respectively (Jeffrey et al., 2001). The daily PET was calculated from Morton's wet environment algorithms (Morton, 1983). Catchment attributes and boundaries were obtained from a dataset generated by Zhang et al. (2013). Apart from the above, this study also used bushfire severity maps obtained from the Victoria Department of Environment, Land, Water \& Planning (https://www.data.vic.gov.au/data/) with an estimated accuracy of $95 \%$, which are shown in red in Fig 1.

\section{Methods}

\subsection{Time-Trend Analysis Method}

Time trend analysis method can be applied in single catchment studies based on the rainfall-runoff relationships in different periods without the need of a control catchment (Bosch \& Hewlett, 1982). This method is mainly used for detecting streamflow changes with vegetation variations due to anthropogenic activities such as plantations or natural variability such as bushfire. This method first constructs and evaluates the regression relationship between rainfall and runoff during the calibration period (the pre-bushfire period in this study), and then estimates streamflow using observed precipitation during the testing period (the postbushfire period in this study). The differences of observed and predicted streamflow represent the vegetation change impacts on streamflow in the testing period. The equation can be expressed as follows (Lee, 1980):

During the calibration period:

$Q_{1}=f\left(P_{1}\right)(1)$

During the testing period:

$Q_{2}^{\prime}=f\left(P_{2}\right)(2)$

$Q^{\mathrm{veg}}=Q_{2}-Q_{2}^{\prime}(3)$

where $P_{1}$ and $P_{2}$ represent annual precipitation $(\mathrm{mm})$ during calibration and testing period respectively. $Q$ represents measured streamflow $(\mathrm{mm})$ and $Q^{\prime}$ represents predicted streamflow $(\mathrm{mm}) \cdot Q^{\text {veg }}$ is the bushfire induced change of average annual streamflow $(\mathrm{mm})$. The function expressed in equation (1) and (2) can be either linear or nonlinear depending on the rainfall-runoff relationships in the specific catchments.

\subsection{Statistics for Evaluation of the Regression relationships}

As mentioned above, the regression model between rainfall and runoff in a catchment should be evaluated once it has been constructed. Following Legates and McCabe Jr (1999), four statistics generally used were applied to indicate the accuracy of the regression relationship between rainfall and runoff, which are: the 
coefficient of determination $\left(R^{2}\right)$, The modified coefficient of efficiency $\left(E_{1}\right)$, the modified index of agreement $\left(d_{1}\right)$, and the mean absolute error (MAE). They are defined as

$R^{2}=\left\{\frac{\sum_{i=1}^{N}\left(O_{i}-O\right)\left(P_{i}-P\right)}{\left[\sum_{i=1}^{N}\left(O_{i}-O\right)\right]^{0.5}\left[\sum_{i=1}^{N}\left(P_{i}-P\right)\right]^{0.5}}\right\}^{2}$

$E_{1}=1.0-\frac{\sum_{i=1}^{N}\left|O_{i}-P_{i}\right|}{\sum_{i=1}^{N}\left|O_{i}-O\right|},(5)$

$d_{1}=1.0-\frac{\sum_{i=1}^{N}\left|O_{i}-P_{i}\right|}{\sum_{i=1}^{N}\left(\left|P_{i}-O\right|+\left|O_{i}-O\right|\right)},(6)$

MAE $=N^{-1} \sum_{i=1}^{N}\left|O_{i}-P_{i}\right|$

where $O$ and $P$ are the observed and predicted data, $O$ and $P$ are the mean value of observed and predicted data, and $\mathrm{N}$ is the number of paired observations.

Confidence limits for the mean (Snedecor \& Cochran, 1989) were designed to indicate a confidence interval for the mean. In our study, a confidence coefficient of $95 \%$ is utilised to represent the confidence limits, which are calculated as:

$Y \pm t_{\left(\frac{\alpha}{2}, N-1\right)} \sigma / \sqrt{N}(8)$

where $Y$ is the mean of the sample, $\sigma$ is the standard deviation of the sample, $\mathrm{N}$ is the size of the sample, $\alpha$ is the significance level, and $t_{\left(\frac{\alpha}{2}, N-1\right)}$ is the upper critical value of thet distribution with $N-1$ degree of freedom. The confidence coefficient is $1-\alpha$.

\subsection{Estimating the Effects of Climate Variability and Bushfire Impact on Stre- amflow}

The total mean annual streamflow changes in a given catchment can be estimated as following:

$Q^{\text {tot }}=Q_{2}^{\text {obs }}-Q_{1}{ }^{\text {obs }}(9)$

where $Q^{\text {tot }}$ is the total changes of mean annual streamflow $(\mathrm{mm}), Q_{1}{ }^{\text {obs }}$ and $Q_{2}{ }^{\text {obs }}$ is the measured mean annual streamflow in the calibration period and testing period respectively.

Climate variables (i.e. rainfall and potential evaporation) and catchment characteristics (i.e. vegetation change) are key aspects that alter hydrological processes. However, the interaction mechanism in the water cycle is complex. For catchments with bushfire impacts, it is assumed that the total changes of mean annual streamflow can be composed of the climate variability induced and the vegetation change induced, which are calculated as

$Q^{\text {tot }}=Q^{\text {clim }}+Q^{\text {veg }}(10)$

where $Q^{\text {clim }}$ and $Q^{\text {veg }}$ is the mean annual streamflow change $(\mathrm{mm})$ caused by climate variability and vegetation change (e.g., bushfire) respectively.

The mean annual streamflow change due to vegetation change can be calculated by time-trend analysis mentioned above while a sensitivity-based method (Dooge et al., 1999; Jones et al., 2006; Schaake \& Liu, 1989 ) is used to estimate the mean annual streamflow change caused by climate variables. This method assumed the changes in catchment water balance are partially attributed to perturbations in climate variables such as precipitation and potential evaporation (PET). Over a sufficiently long time scale, change in mean annual streamflow due to climate change can be calculated as (Koster \& Suarez, 1999; Milly \& Dunne, 2002):

$Q^{\mathrm{clim}}=a P+b P E T(11)$ 
where $P$ and $P E T$ represent the changes in precipitation $(\mathrm{mm})$ and potential evaporation $(\mathrm{mm})$, and a, $\mathrm{b}$ are the sensitivity coefficients of streamflow to precipitation and potential evaporation, which can be obtained from the Budyko-curve model proposed by Zhang et al. (2001) as following description (Li et al., 2007):

$a=\frac{1+2 x+3 w x^{2}}{\left(1+x+w x^{2}\right)^{2}}$

$b=\frac{1+2 w x}{\left(1+x+w x^{2}\right)^{2}}$

where $\mathrm{x}$ is the dryness index $(\mathrm{PET} / \mathrm{P})$ and $w$ is a model parameter associated with catchment characteristics (Zhang et al., 2001). The value of $w$ was determined by climatic condition and vegetation cover in a given catchment before bushfire and was kept constant in the whole period.

\subsection{Determination of the Calibration and Testing Periods}

In this study, we are focusing on catchments affected by the 2009 Victoria bushfire event. The calibration period was determined according to the data quality and length of streamflow data in each catchment (See Table 1). Once the calibration period was determined, annual rainfall and streamflow data were utilized to develop a regression relationship for the catchment. The testing period of all catchments was set to be 2009-2015 since the bushfire occurred in early February, 2009 and the dataset of climate variables and streamflow until pre-2016 were collated. Annual precipitation, PET and streamflow were divided into two parts to represent the calibration and testing periods.

\section{Results}

\subsection{Regression Analysis in the Calibration Periods}

Rainfall-runoff relationships in the calibration and testing periods were examined before developing the regression relationships. For example, in severely burnt catchments such as Flowerdale, Taggerty and Koornalla (with burnt percentages of $96.6 \%, 89.7 \%$ and $83.1 \%$ respectively), there are obvious changes in the rainfall-runoff relationship in the testing period compared with that in the calibration period (see Figure 3 ). Similar results were obtained in the majority of the selected catchments and the extent of the relationship change is related to the burnt percentage as well as the burnt severity. The results illustrate that there is more streamflow after the vegetation loss caused by bushfire, which is consistent with our knowledge of how bushfire affects streamflow in a catchment. This provides confidence in our further analysis of bushfire impacts on streamflow.

Then, the regression relationships between rainfall and streamflow were constructed before quantifying the bushfire and climate change impacts on mean annual streamflow. The rainfall-streamflow relationship varies largely from catchment to catchment in different time periods. In this study, relationship between rainfall and streamflow in almost every catchment impacted by bushfire can be fitted by linear regression model in both calibration period and testing period (see Figure 3) and the evaluation results of the regression model are listed in Table 2.

$<$ Figure 3 Here Please $>$

Figure 3 shows the regression relationships obtained for each catchment in the calibration and test periods and Table 2 summarizes the statistical metrics of the linear regressions. There exist good linear relationships between annual rainfall and annual streamflow in most catchments in the calibration periods (Figure 3). The coefficient of determination $\left(R^{2}\right)$ result varying from 0.56 to 0.85 indicates annual rainfall explains $56 \%-85 \%$ variation of annual streamflow in the calibration periods (Table 2). The modified coefficient of efficiency $\left(E_{1}\right)$ ranges from 0.26-0.65 and the modified index of agreement $\left(d_{1}\right)$ ranges from 0.62 to 0.82 . The mean absolute error (MAE) is in the range of 16.3-101.8. These results indicate that the linear regressions are satisfactory 
in most of burnt catchments, and can be used for estimating the streamflow under a given precipitation during the testing period (i.e. the post-bushfire period).

$<$ Table 2 Here Please $>$

\subsection{Bushfire and Climate Variability Impacts on Mean Annual Streamflow}

To evaluate the total mean annual streamflow changes in the testing period, the total annual streamflow change $\left(\Delta \mathrm{Q}^{\text {tot }}\right)$ were calculated based on Equation 10 and the results are summarized in Table 3. The total mean annual streamflow of all the catchments increases in the testing period (post-bushfire period), compared with the calibration period (pre-bushfire period) except for Jamieson (with decline of $22.3 \mathrm{~mm}$ ). The increase in mean annual streamflow ranges from 5.9 to $141.4 \mathrm{~mm}$. 12 out of the 15 selected catchments have increasing average runoff ratio in the testing period, which varies from 0.002 to 0.106 . In contrast, the average runoff ratio of Running Creek and Tallarook decreases by 0.009 and 0.03 respectively while Frenchman Creek Junction's average runoff ratio remains stable.

To quantify the contribution of bushfire effects to the mean annual streamflow change, streamflow changes due to vegetation change caused by bushfire $\left(\Delta \mathrm{Q}^{\mathrm{veg}}\right)$ were determined from time trend analysis method (see 3.1). As shown in Table 3, the calculated streamflow increase due to vegetation change caused by bushfire $\left(\Delta \mathrm{Q}^{\mathrm{veg}}\right.$ ) ranges from 1.6 (Frenchman Creek Junction) to $125.9 \mathrm{~mm}$ (Traralgon South) or $-45 \%$ (Jamieson) to $98 \%$ (Murrindindi above) of the observed total streamflow change $\left(\Delta \mathrm{Q}^{\mathrm{tot}}\right)$. The results indicate that the bushfire caused streamflow increases during the testing period in each burnt catchment.

Changes in rainfall and potential evaporation (PET) also contribute to streamflow variations. Thus, the streamflow changes due to climate variability $\left(\Delta \mathrm{Q}^{\text {clim }}\right)$ were determined from sensitivity-based method (see 3.3 ). The choice of $w$ value in sensitivity-based method was based on climate condition and agreement in the calibration period between measured and estimated annual runoff ratio (Zhang et al., 2011). The $w$ value remained constant in testing period to ensure equation 11 only represents the effect of climate variability. Table 3 shows that climate variability in the testing period increases annual streamflow in the majority of catchments such as Running Creek and Rosewhite, but decreases annual streamflow in the rest (e.g., Jamieson and Koornalla). The proportion of streamflow change due to climate variability in total streamflow change ranges from $-7 \%$ to $157 \%$.

$<$ Table 3 Here Please $>$

In this study, percentage changes in mean annual streamflow caused by bushfire and climate variability were calculated independently. When the sum of the two percentage changes approaches $100 \%$, it means that the independent simulated streamflow changes are close to the actual streamflow changes. Figure 4 summarizes the sum of the two proportions. For most catchments except for Frenchman Creek Junction, the sum is close to $100 \%$, which means the sum of streamflow change due to bushfire $\left(\Delta \mathrm{Q}^{\mathrm{veg}}\right)$ and climate variability $\left(\Delta \mathrm{Q}^{\text {clim }}\right)$ approaches the total streamflow change $\left(\Delta \mathrm{Q}^{\text {tot }}\right)$. This indicates that the two independent methods are reliable for most of the bushfire impacted catchments. The reason why Frenchman Creek Junction only has $28 \%$ total streamflow change is because the absolute streamflow change before and after bushfire is only $5.9 \mathrm{~mm}$. Such a small change may amplify the error of the actual total change of streamflow and the sum of estimated streamflow change from bushfire and climate variability. As shown in Figure 4, streamflow change between the two periods (pre- and post- bushfire periods) is mainly contributed by bushfire impact in 11 catchments, but by climate variability in the other 3 . It is worth noting that among all the burnt catchments, only Jamieson has a decrease in streamflow after bushfire. This occurs because the streamflow change caused by bushfire increased but the climate variability induced a greater decrease in streamflow, which is consistent with the fact that Jamieson only has $36.3 \%$ burnt area with less burnt severity (see Figure 2 ) and the rainfall in the testing period is lower compared with the calibration period (see Figure 1).

$<$ Figure 4 Here Please $>$

To further investigate if the bushfire impacts on streamflow are related to the burnt area, Figure 5 shows 
the relationship between burnt percentage (fire scars area within a catchment as a proportion of the total area of a catchment) and percentage of mean annual streamflow increase due to bushfire. It is shown that the percentage of mean annual streamflow increase due to bushfire is strongly related to the percentage area burnt. The linear relationship between the two indicate the burnt percentage can explain $68 \%$ of the percentage of mean annual streamflow increase due to bushfire. This result can be used to estimate or predict the annual streamflow changes due to bushfire if the burnt percentage for a small to medium sized catchment is available. It is worth noting that the relationship is suitable at annual time scale and may be not appropriate at sub-annual time steps.

$<$ Figure 5 Here Please $>$

\section{Discussion}

Vegetation change and climate variability were considered as main factors affecting annual streamflow in this study, and the evaluation of such impacts were implemented at mean annual scale. At seasonal or monthly time scale, the climate variability impact on streamflow may be different since the streamflow would be impacted by the seasonality of rainfall which adds an additional layer of complexity. Another time scale issue which should be focused on is the period selected for bushfire impact assessment. This study mainly focuses on an immediate post bushfire period. When the bushfire period considered is extended the increased impact can be subdued due to regrowth and runoff will decrease when there is more vegetation.

In this study, the estimation of streamflow change due to climate variability was calculated by a sensitivitybased method based on the Budyko framework (Budyko, 1958). This study not only tested the method of Zhang et al., (2001), but also other Budyko curves such as Fu curves (Fu, 1981) and both methods yield similar results. These tests further indicate that Budyko curves are robust for estimating mean annual streamflow change induced by climate variability. Generally speaking, the approach can yield more reliable results if multiple linear regression considered PET as well as $\mathrm{P}$ as descriptors to predict the mean annual streamflow during the testing period. For this reason, the multilinear regression considering $\mathrm{P}$ and PET was tested as well. Overall, the fitting coefficient of determination $\left(R^{2}\right)$ of single linear regression $(0.74)$ and multiple linear regression (0.76) are very similar. In addition, the proportion of bushfire and climate variability impact on streamflow didn't show a dramatic change when the single regression was replaced by multiple regression. As a result, we conclude that the linear regression relationships between annual rainfall and annual streamflow are satisfactory for estimating vegetation change induced impacts on streamflow.

As shown in Figure 5, the relationship can be described by a linear regression model. The fitting coefficient of determination $\left(R^{2}\right)$ is 0.69 which is satisfactory. it is possible to further improve quantitation of the relationship between burnt percentage and percentage of mean annual streamflow increase due to bushfire, which is constructed to specify how bushfire extent influences the bushfire impact on streamflow.

This study uses two independent methods to estimate the effects of vegetation change caused by bushfire and climate variability on annual streamflow. The independent evaluation of the two impacts show that the time-trend analysis and sensitivity-based methods are accurate for our research purpose. Further, to meet the assumption that climate variability and bushfire are the main dominant factors to affect the streamflow, efforts has been made when choosing these target catchments (i.e. adequate data record and impacted by bushfire to certain extent). Our study clearly indicates the burnt percentage shows a good positive relationship with percentage of mean annual streamflow change due to bushfire, which suggests higher and more serious burnt percentage contributes a greater increase in streamflow. 


\section{Conclusion}

This study selected 14 bushfire impacted catchments during the 2009 Victoria bushfire event and analysed the effects of the bushfire as well as climate variability on annual streamflow. Relationships between rainfall and streamflow in all catchments have been constructed and evaluated during the calibration period. Then the relationships were applied to estimate the annual streamflow changes due to bushfire in the time-trend analysis method. The calculated streamflow increase due to vegetation change caused by bushfire $\left(\Delta \mathrm{Q}^{\mathrm{veg}}\right)$ ranges from $1.6 \mathrm{~mm}$ (Frenchman Creek Junction) to $125.9 \mathrm{~mm}$ (Traralgon South), which illustrates that the bushfire caused an increase in streamflow during the post-fire (testing) period in all burnt catchments. The streamflow changes due to climate variability $\left(\Delta \mathrm{Q}^{\text {clim }}\right)$ were determined from the sensitivity-based method. The result shows that streamflow changes caused by climate variability in the majority of catchments has relatively smaller proportions of total streamflow change compared with that caused by bushfire. The relationship between burnt percentage and percentage of mean annual streamflow increase due to bushfire was constructed and the results indicate that the percentage increase in mean annual streamflow due to bushfire is linearly related to percentage burnt areas. This relationship can be used to estimate the annual streamflow changes caused by bushfire in small-medium size catchments in Australia.

\section{Acknowledgments}

This study was supported by CAS Pioneer Hundred Talents Program and the National Natural Science Foundation of China (Grant No. 41971032). We thank the OzEWEX (the Australian Energy and Water Exchange Research Initiative) to hold the summer institute and the financial support from China Scholarship Council. The authors declare no conflict of interest.

\section{Data Availability Statement}

The data that support the findings of this study are openly available in CSIRO Research Publications Repository at https://doi.org/10.4225/08/58b5baad4fcc2.

\section{References}

Anderson, H. W., Hoover, M. D., \& Reinhart, K. G. (1976). Forests and water: effects of forest management on floods, sedimentation, and water supply. General Technical Report PSW-018. Berkeley, CA: US Department of Agriculture, Forest Service, Pacific Southwest Forest Range Experiment Station., 18 .

Biondi, D., \& De Luca, D. L. (2015). Process-based design flood estimation in ungauged basins by conditioning model parameters on regional hydrological signatures. Natural Hazards, 79 (2), 1015-1038. doi:10.1007/s11069-015-1889-1

Bosch, J. M., \& Hewlett, J. (1982). A review of catchment experiments to determine the effect of vegetation changes on water yield and evapotranspiration. Journal of Hydrology, 55 (1-4), 3-23.

Brown, A. E., Zhang, L., McMahon, T. A., Western, A. W., \& Vertessy, R. A. (2005). A review of paired catchment studies for determining changes in water yield resulting from alterations in vegetation. Journal of Hydrology, 310 (1-4), 28-61.

Brown, J. A. H. (1972). Hydrologic effects of a bushfire in a catchment in south-eastern New South Wales. Journal of Hydrology, 15 (1), 77-96.

Budyko, M. (1958). The heat balance of the earth's surface, . Washington, DC, USA: US Dept. of Commerce, Weather Bureau. 
Cai, W. J., Cowan, T. D., \& Raupach, M. R. (2009). Positive Indian Ocean Dipole events precondition southeast Australia bushfires. Geophysical Research Letters, 36 (19), 387-390.

Campbell, R. S. (1999). Hydrogeology of a small forested catchment. University of Melbourne, Department of Earth Sciences,

Daniell, T., \& Kulik, V. (1987). Bushfire hydrology —The case of leaking watersheds. Journal of Hydrology, 92 (3-4), 301-313.

Dooge, J., Bruen, M., \& Parmentier, B. (1999). A simple model for estimating the sensitivity of runoff to long-term changes in precipitation without a change in vegetation. Advances in Water Resources, 23 (2), 153-163.

Feikema, P. M., Sherwin, C. B., \& Lane, P. N. (2013). Influence of climate, fire severity and forest mortality on predictions of long term streamflow: potential effect of the 2009 wildfire on Melbourne's water supply catchments. Journal of Hydrology, $488,1-16$.

Folton, N., Andréassian, V., \& Duperray, R. (2015). Hydrological impact of forest-fire from paired-catchment and rainfall-runoff modelling perspectives. Hydrological Sciences Journal, 60 (7-8), 1213-1224.

Foster, L., Adams, M., \& Attiwill, P. (2011). Epilogue: The final report of the 2009 Victorian bushfires royal commission. Clayton: Csiro Publishing.

Fu, B. (1981). On the calculation of the evaporation from land surface.Sci. Atmos. Sin, 5 (1), 23-31.

Heath, J., Chafer, C., Van Ogtrop, F., \& Bishop, T. (2014). Post-wildfire recovery of water yield in the Sydney Basin water supply catchments: An assessment of the 2001/2002 wildfires. Journal of Hydrology, 519 , 1428-1440.

Jeffrey, S. J., Carter, J. O., Moodie, K. B., \& Beswick, A. R. (2001). Using spatial interpolation to construct a comprehensive archive of Australian climate data. Environmental Modelling \& Software, 16 (4), 309-330.

Jones, R. N., Chiew, F. H., Boughton, W. C., \& Zhang, L. (2006). Estimating the sensitivity of mean annual runoff to climate change using selected hydrological models. Advances in Water Resources, 29 (10), 1419-1429.

Koster, R. D., \& Suarez, M. J. (1999). A simple framework for examining the interannual variability of land surface moisture fluxes. Journal of Climate, 12 (7), 1911-1917.

Lane, P. N., Best, A. E., Hickel, K., \& Zhang, L. (2005). The response of flow duration curves to afforestation. Journal of Hydrology, 310 (1-4), 253-265.

Lee, R. (1980). Forest hydrology : Columbia University Press.

Legates, D. R., \& McCabe Jr, G. J. (1999). Evaluating the use of "goodness-of-fit" measures in hydrologic and hydroclimatic model validation. Water Resources Research, 35 (1), 233-241.

Li, L. J., Zhang, L., Wang, H., Wang, J., Yang, J. W., Jiang, D. J., . . . Qin, D. Y. (2007). Assessing the impact of climate variability and human activities on streamflow from the Wuding River basin in China.Hydrological Processes: An International Journal, 21 (25), 3485-3491.

Liu, S., Leslie, L., Speer, M., Bunker, R., \& Mo, X. (2004). The effects of bushfires on hydrological processes using a paired-catchment analysis. Meteorology Atmospheric Physics, 86 (1-2), 31-44.

Loon, A. F. V., Rangecroft, S., Coxon, G., Brena Naranjo, J. A., Ogtrop, F. V., \& Van Lanen, H. A. (2019). Using paired catchments to quantify the human influence on hydrological droughts. Hydrology Earth System Sciences, 23 (3), 1725-1739.

Mannik, R., Herron, A., Hill, P., Brown, R., \& Moran, R. (2013). Estimating the change in streamflow resulting from the 2003 and 2006/2007 Bushfires in southeastern Australia. Australasian Journal of Water 
Resources, 16 (2), 107-120.

Milly, P., \& Dunne, K. (2002). Macroscale water fluxes 2. Water energy supply control of their inter-annual variability, Water Resources Research, 38 (10), 241-249.

Morton, F. I. (1983). Operational estimates of areal evapotranspiration and their significance to the science and practice of hydrology.Journal of Hydrology, 66 (1-4), 1-76.

Neary, D. G., Klopatek, C. C., DeBano, L. F., \& Ffolliott, P. F. (1999). Fire effects on belowground sustainability: a review and synthesis. Forest Ecology Management, 122 (1-2), 51-71.

Papathanasiou, C., Makropoulos, C., \& Mimikou, M. J. J. o. H. (2015). Hydrological modelling for flood forecasting: calibrating the post-fire initial conditions. 529 , 1838-1850.

Pathiraja, S., Marshall, L., Sharma, A., \& Moradkhani, H. (2016). Detecting non-stationary hydrologic model parameters in a paired catchment system using data assimilation. Advances in Water Resources, 94 , 103-119.

Robichaud, P. R., Beyers, J. L., \& Neary, D. G. (2000).Evaluating the effectiveness of postfire rehabilitation treatments : US Department of Agriculture, Forest Service, Rocky Mountain Research ....

Schaake, J., \& Liu, C. (1989). Development and application of simple water balance models to understand the relationship between climate and water resources. Paper presented at the New Directions for Surface Water Modeling Proceedings of the Baltimore Symposium.

Seibert, J., McDonnell, J. J., \& Woodsmith, R. D. (2010). Effects of wildfire on catchment runoff response: a modelling approach to detect changes in snow-dominated forested catchments. Hydrology Research, 41 (5), 378-390.

Shakesby, R., \& Doerr, S. (2006). Wildfire as a hydrological and geomorphological agent. Earth-Science Reviews, 74 (3-4), 269-307.

Snedecor, G. W., \& Cochran, W. G. (1989). Statistical methods, 8thEdn.Ames: Iowa State Univ. Press Iowa .

Tiedemann, A., Conrad, C., Dieterich, J., Hornbeck, J., Megahan, W., Viereck, L., \& Wade, D. (1979). Effects of fire on water. A state-of-art review. In General Technical Report WO (Vol. 10): United States Department of Agriculture, Forest Service.

Tuteja, N. K., Vaze, J., Teng, J., \& Mutendeudzi, M. (2007). Partitioning the effects of pine plantations and climate variability on runoff from a large catchment in southeastern Australia. Water Resources Research, $43(8)$.

Zegre, N., Skaugset, A. E., Som, N. A., McDonnell, J. J., \& Ganio, L. M. (2010). In lieu of the paired catchment approach: Hydrologic model change detection at the catchment scale. Water Resources Research, $46(11)$.

Zhang, L., Dawes, W., \& Walker, G. (2001). Response of mean annual evapotranspiration to vegetation changes at catchment scale. Water Resources Research, 37 (3), 701-708.

Zhang, L., Zhao, F., Chen, Y., \& Dixon, R. N. (2011). Estimating effects of plantation expansion and climate variability on streamflow for catchments in Australia. Water Resources Research, 47 (12).

Zhang, X., Zhang, L., Zhao, J., Rustomji, P., \& Hairsine, P. (2008). Responses of streamflow to changes in climate and land use/cover in the Loess Plateau, China. Water Resources Research, 44 (7).

Zhang, Y., Viney, N., Frost, A., Oke, A., Brooks, M., Chen, Y., \& Campbell, N. (2013). Collation of Australian modeller's streamflow dataset for 780 unregulated Australian catchments. Water for a Healthy Country National Research Flagship, 1-115. 
Zhao, F., Xu, Z., \& Zhang, L. (2012). Changes in streamflow regime following vegetation changes from paired catchments. Hydrological Processes, 26 (10), 1561-1573.

Zhao, F., Zhang, L., Xu, Z., \& Scott, D. F. (2010). Evaluation of methods for estimating the effects of vegetation change and climate variability on streamflow. Water Resources Research, 46 (3).

Zhou, Y., Zhang, Y., Vaze, J., Lane, P., \& Xu, S. (2015). Impact of bushfire and climate variability on streamflow from forested catchments in southeast Australia. Agricultural Hydrological Sciences Journal, 60 (7-8), 1340-1360.

\section{Tables}

Table 1 . Summary of the 14 selected burnt catchments for bushfire impact analysis

\begin{tabular}{ll}
\hline Catchment & Latitude \\
Rosewhite & $36.58^{\circ} \mathrm{S}$ \\
Flowerdale & $37.35^{\circ} \mathrm{S}$ \\
Devlins Br & $37.38^{\circ} \mathrm{S}$ \\
Murrindindi above Colwells & $37.41^{\circ} \mathrm{S}$ \\
Taggerty & $37.32^{\circ} \mathrm{S}$ \\
Rubicon & $37.29^{\circ} \mathrm{S}$ \\
Neerim & $37.97^{\circ} \mathrm{S}$ \\
Tonimbuk & $38.02^{\circ} \mathrm{S}$ \\
Koornalla & $38.32^{\circ} \mathrm{S}$ \\
Frenchman Ck Jun & $37.52^{\circ} \mathrm{S}$ \\
Traralgon South & $38.27^{\circ} \mathrm{S}$ \\
Running Ck & $36.54^{\circ} \mathrm{S}$ \\
Jamieson & $37.37^{\circ} \mathrm{S}$ \\
Tallarook & $37.10^{\circ} \mathrm{S}$ \\
a, b, c The mean annual rainfall, PET and streamflow are calculated over the entire record period. & ${ }^{2}, \mathrm{~b}, \mathrm{c}$ The mean annual \\
\hline
\end{tabular}

Table 2 . Statistical results of linear regressions between annual rainfall and annual streamflow in the 14 burnt catchments during the calibration periods

\begin{tabular}{lllllll}
\hline Catchment & Calibration Period & $\mathrm{N}$ & $R^{2}$ & $E_{1}$ & $d_{1}$ & MAE(mm) \\
\hline Rosewhite & $2000-2009$ & 8 & 0.71 & 0.46 & 0.70 & 34.1 \\
Flowerdale & $1990-2009$ & 19 & 0.77 & 0.52 & 0.75 & 46.5 \\
Devlins Br & $1990-2009$ & 19 & 0.82 & 0.59 & 0.78 & 51.7 \\
Murrindindi above Colwells & $1990-2009$ & 19 & 0.69 & 0.45 & 0.71 & 78.4 \\
Taggerty & $1990-2009$ & 19 & 0.82 & 0.60 & 0.79 & 62.4 \\
Rubicon & $1990-2009$ & 19 & 0.81 & 0.55 & 0.76 & 102.7 \\
Neerim & $1990-2009$ & 19 & 0.71 & 0.51 & 0.74 & 35.2 \\
Tonimbuk & $1975-2009$ & 33 & 0.56 & 0.33 & 0.62 & 43.6 \\
Koornalla & $1980-2009$ & 29 & 0.72 & 0.50 & 0.75 & 40.4 \\
Frenchman Ck Jun & $1980-2009$ & 29 & 0.77 & 0.53 & 0.75 & 67.0 \\
Traralgon South & $1998-2009$ & 11 & 0.77 & 0.49 & 0.74 & 16.3 \\
Running Ck & $2000-2009$ & 9 & 0.69 & 0.44 & 0.69 & 37.9 \\
Jamieson & $1971-2009$ & 38 & 0.85 & 0.65 & 0.82 & 59.2 \\
Tallarook & $2000-2009$ & 9 & 0.71 & 0.26 & 0.64 & 22.2 \\
\hline
\end{tabular}


Table 3 . Estimating vegetation change-induced mean annual streamflow change

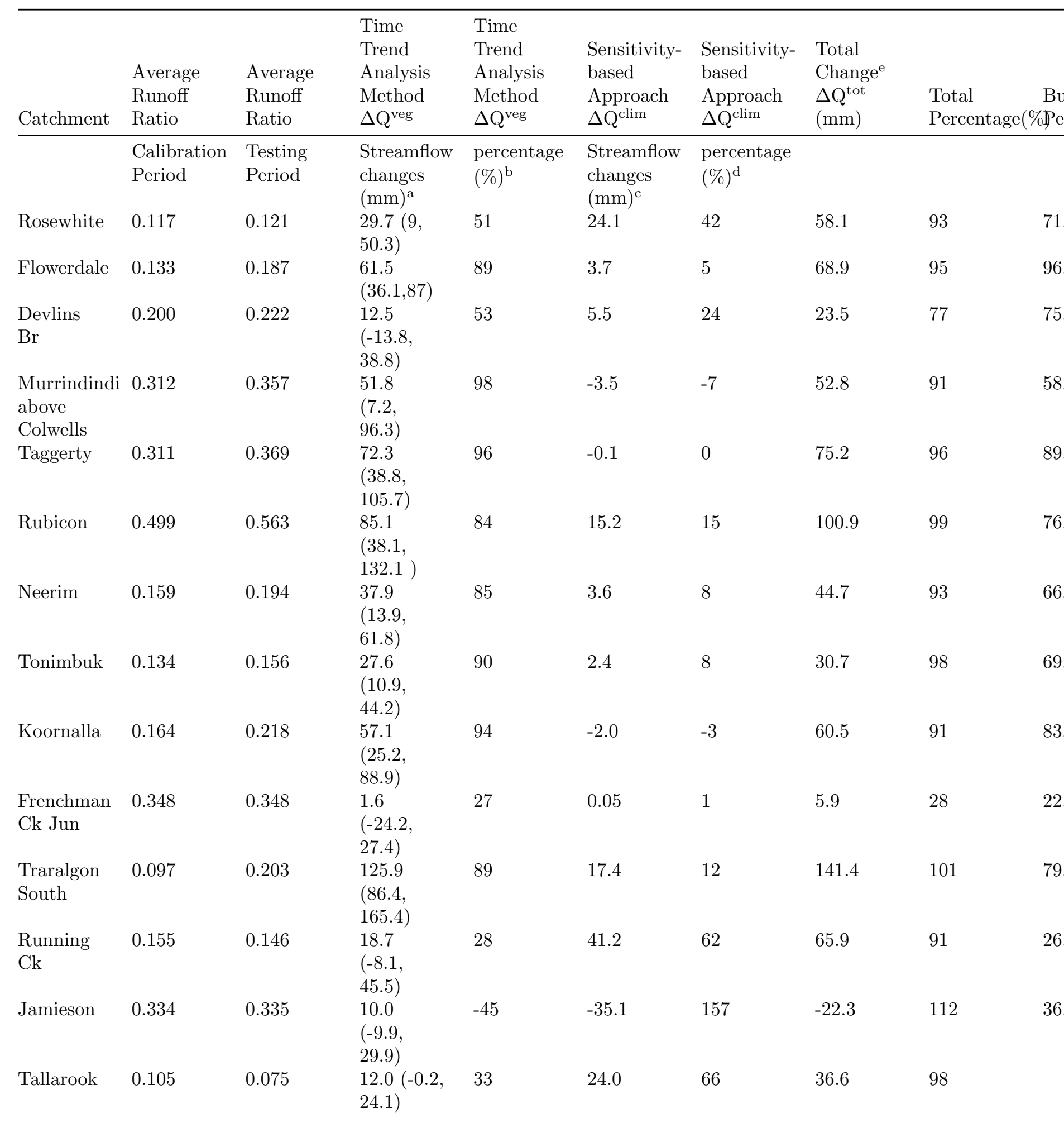




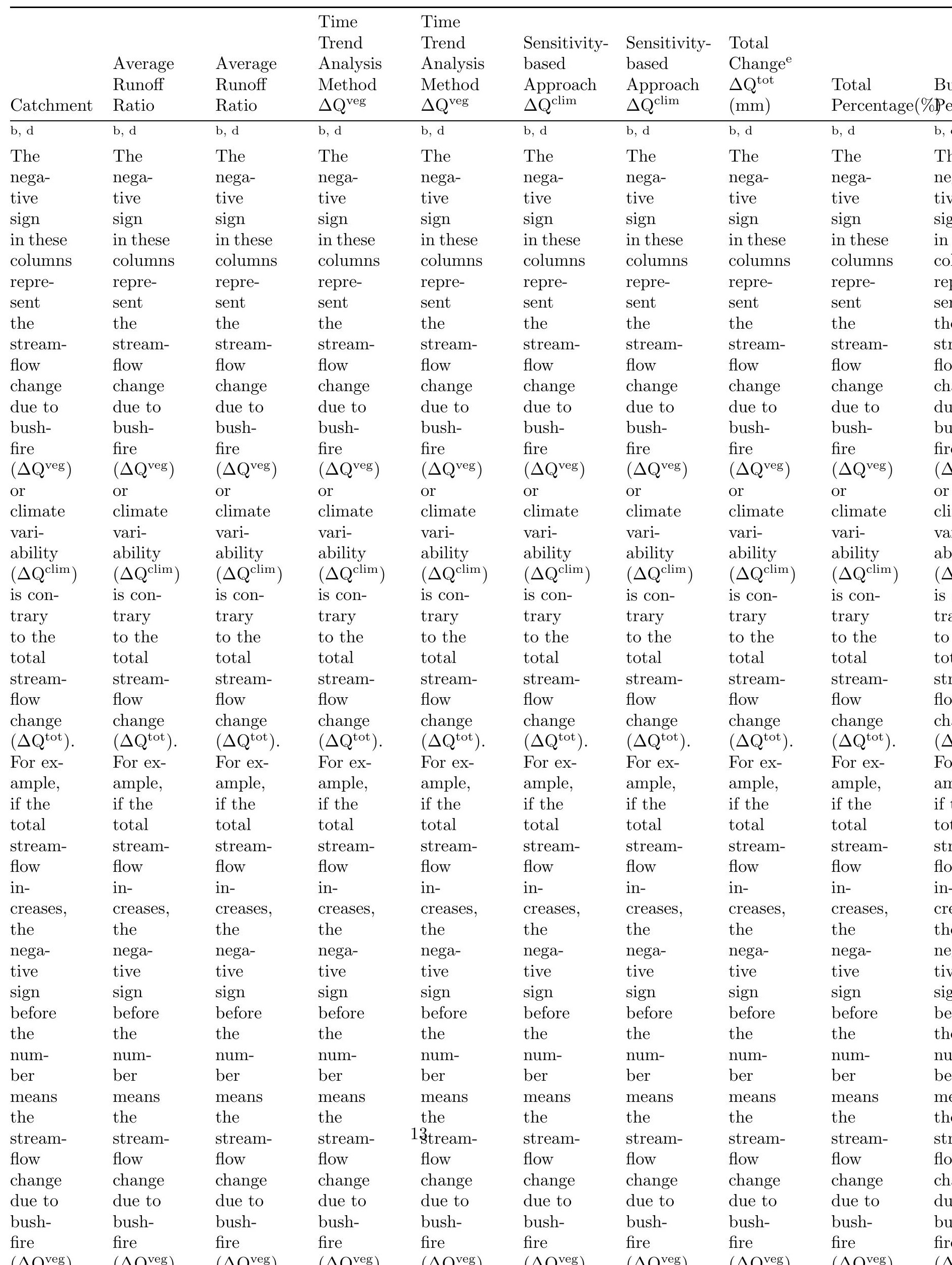




\begin{tabular}{|c|c|c|c|c|c|c|c|c|}
\hline & Average & Average & $\begin{array}{l}\text { Time } \\
\text { Trend } \\
\text { Analysis }\end{array}$ & $\begin{array}{l}\text { Time } \\
\text { Trend } \\
\text { Analysis }\end{array}$ & $\begin{array}{l}\text { Sensitivity- } \\
\text { based }\end{array}$ & $\begin{array}{l}\text { Sensitivity- } \\
\text { based }\end{array}$ & $\begin{array}{l}\text { Total } \\
\text { Change }^{\mathrm{e}}\end{array}$ & \\
\hline & Runoff & Runoff & Method & Method & Approach & Approach & $\Delta \mathrm{Q}^{\mathrm{tot}}$ & Total $\quad \mathrm{B}$ \\
\hline Catchment & Ratio & Ratio & $\Delta Q^{\text {veg }}$ & $\Delta Q^{\text {veg }}$ & $\Delta \mathrm{Q}^{\text {clim }}$ & $\Delta \mathrm{Q}^{\text {clim }}$ & $(\mathrm{mm})$ & Percentage $\%$ Pe \\
\hline
\end{tabular}

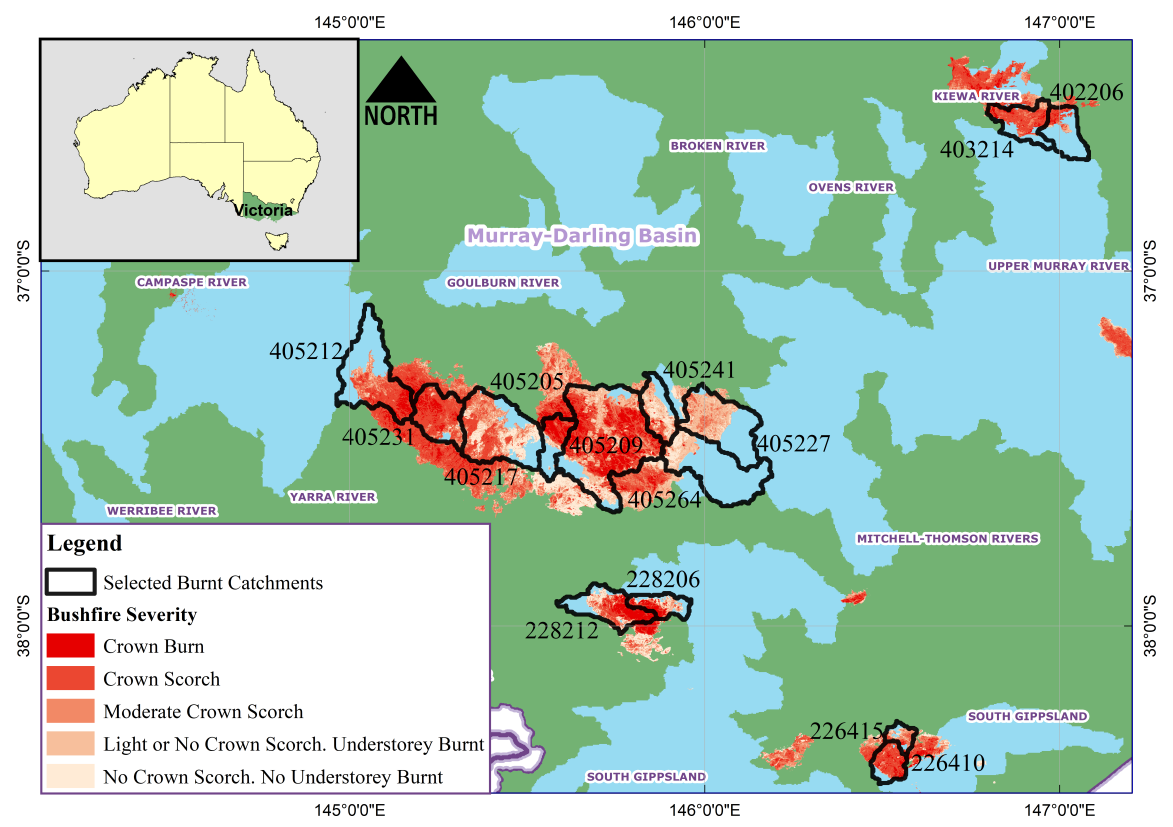


figures/severity-proportion/severity-proportion-eps-converted-to.pdf 
figures/RR-plot/RR-plot-eps-converted-to.pdf 
figures/radar-plot/radar-plot-eps-converted-to.pdf 
figures/scatter-plot/scatter-plot-eps-converted-to.pdf 